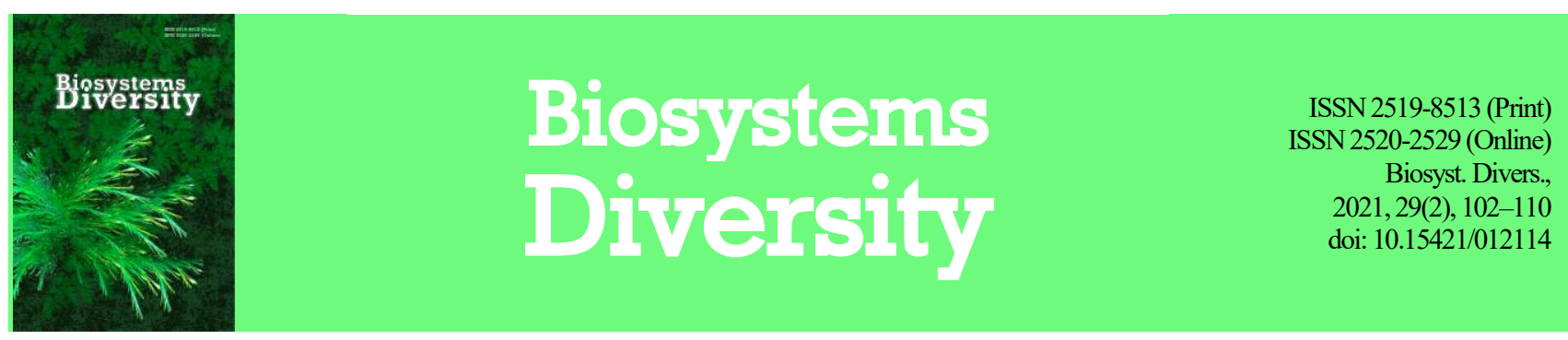

\title{
Anthropogenic load is a leading factor in the morphological variability of Chondrula tridens (Gastropoda, Enidae) in the northwestern Azov Sea region
}

\author{
O. I. Koshelev*, M. V. Gensytskyi*, V. O. Koshelev*, N. V. Yorkina*, O. M. Kunakh** \\ *Bogdan Khmelnitsky Melitopol State Pedagogical University, Melitopol, Ukraine \\ **Oles Honchar Dnipro National University, Dnipro, Ukraine
}

Article info

Received 01.04.2021

Received in revised form 05.05 .2021

Accepted 06.05.2021

Bogdan Khmelnitsk

Melitopol State

Pedagogical University,

Hetmanska st., 20

Melitopol, 72318, Ukraine

Tel.: +38-098-558-37-55.

E-mail:

aikoshelev4971@gmail.com

Oles Honchar Dnipro

National University

Gagarin av., 72

Dnipro, 49000, Ukraine.

Tel.: + 38-098-858-23-79.

E-mail:kunah_olga@ukr.net

Koshelev, O. I., Gensytskyi, M. V., Koshelev, V. O., Yorkina, N. V., \& Kunakh, O. M. (2021). Anthropogenic load is a leading factor in the morphological variability of Chondrula tridens (Gastropoda, Enidae) in the northwestern Azov Sea region. Biosystems Diversity, 29(2), 102-110. doi:10.15421/012114

Morphometric data are widely used in biology to assess intraspecific and inter-population variability and for bioindication and environmental condition assessment. The following hypotheses have been experimentally tested in the paper: 1) the vegetation type affects the change in the shell shape of Chondrula tridens martynovi Gural-Sverlova \& Gural, 2010;2) the change in the shell shape of this species is influenced by the biotope moisture regime; 3 ) the shell shape changes depending on the anthropogenic load level. The material in the form of empty, fully formed Ch. tridens shells was collected in 2019 in the north-western Azov region within the basin of the Molochna River. The collection points were located in settlements and outside them and differed in vegetation, moisture regime and level of anthropogenic load. The vegetation has been expertly attributed to two alternative types: herbaceous vegetation and tree plantations. By moisture level, the locations have been assessed as xerophytic and mesoxerophytic. The anthropogenic load levels have been assessed as low, medium and high. The study revealed that the morphological characteristics of $C h$. tridens demonstrate a significant component of variability, which is due to the shell size. The shell size depends on the anthropogenic impact level. Under conditions of high anthropogenic impact, the shell size increases. Mollusks from locations with low and medium anthropogenic impact levels did not differ in shell size. After extraction of the size component, morphological properties develop three main trends of variability. The mouth apparatus development of mollusks does not depend on the vegetation type, but depends on the biotope moisture level and the anthropogenic transformation level. The mollusk shell elongation was observed to have the opposite dynamics of the height parameters in relation to the width and depended on the level of anthropogenic load. Rearrangement in the mouth apparatus depended on the biotope moisture level and the anthropogenic load level. There were distinguished four clusters, the quantitative morphological features of which allowed us to identify them as morphotypes. Each location was characterized by a combination of different morphotypes, according to which the sampling points may be classified. Morphotype 1 corresponds to biotopes with low level of anthropogenic load, morphotype 4 corresponded to biotopes with high anthropogenic load. Morphotypes 2 and 3 corresponded to moderate level of anthropogenic load. Vegetation type is not an important factor in determining the morphotypic diversity of populations. Under xerophytic conditions, morphotypes 2 and 3 are more common, and under mesoxerophytic conditions, morphotypes 1 and 4 are more common. The range of molluses in different habitats needs to be expanded in the future to clarify climatic and other patterns.

Keywords: terrestrial mollusks; variability; conchological characteristics; morphometric analysis.

\section{Introduction}

From an evolutionary point of view, gastropods are one of the most diverse mollusk groups, characterized by extraordinary biodiversity and the ability to adapt to different environmental conditions (Barker, 2005). Genetically determined variations in shell shape and size are well known, but at the same time, the environment plays a key role in the shell development (Welter-Schultes, 2001). Differences between populations may be accompanied by variability in shell sizes within a species (Madec, 2003). There is a significant difference not only in the linear dimensions of the shell depending on climatic factors and environmental conditions, but also in the growth rate of the coils. It is suitable for climate change indication due to its sensitivity to environmental factors (Anderson, 2007). Large species of land snails are convenient objects for studying morphological variability and characteristics of the life cycle on a relatively small ecological scale and are used as model organisms for studying ecological genetics (Davison, 2002). To study the morphometric variability of species, it is necessary to take into account their habitat conditions (Anderson et al., 2010; Manel et al., 2010; Thomassen et al., 2010). However, in order to fully understand the structure of a species which has an extremely wide habitat, research must be carried out in other areas too. In general, environmental parameters influenced by plant communities strongly correlate with distribution of terrestrial mollusks (Martin et al., 2004). For example, most mollusks are physiologically restricted to the areas with higher calcium and $\mathrm{pH}$ levels in the soil, which are usually associated with broadleaf trees (Martin et al., 2004). Although genetic variation has not been explored in this study, the observed phenotypic variation may be reflected in the snail's ability to change its growth shape or develop alternative phenotypes according to current environmental conditions (Goodfriend, 1986; Wagele, 2004; Miner et al., 2005). It is a measure of their adaptive strategy to minimize the loss of fitness in harsher conditions or maximize fitness in a supportive environment (Madjos et al., 2015). The reasons for the prosperity (or, conversely, the oppressed state) of the group depend on external factors (of climate), soil, topographic features, geological region history, human activity), as well as the peculiarities of the organization of the animals themselves. However, the "organizational features" may include not only morphological, but also physiological, biochemical and ethological properties of organisms (Schileyko, 2016).

Chondrula tridens is a European, steppe calciphilous species. It is widespread in Europe from the southwest of France to the northwest of Iran and the Urals, including the Crimea and the Caucasus, bypassing the northern part of the continent (Riedel, 1988). The species reaches the northern border of its range in Lithuania. The southem border of the range is in northern Turkey and Northern Iraq (Welter-Schultes, 2012). Chondrula tridens is characterized by significant intraspecific variability of the shell size (Kerney et al., 1983; Schileyko, 1984), shape (Kramarenko 
et al., 2003, 2006; Gural Sverlova et al., 2010) and development of the mouth armature (Snegin, 2011a, 2011b). The species occurs in the steppes as an index species of the Early Holocene in Central Europe (Leicht et al., 2017). In modern Central Europe, it is traditionally associated with managed pastures in many countries such as France, Luxembourg, Switzerland, Germany. In the Southern Urals, it occurs not only in different types of meadows, but also in maple-elm forests with alkaline soil in a closed canopy, far from forest edges (Horsák et al., 2010), as well as in the East of Russia and neighbouring countries (Sysoev et al., 2009). The species was also found in the Ryazan region, the steppe zone to the Ural River in the east and the forest-steppe and some forest zones in the Ukraine, the Carpathians, Crimea, the Caucasus (Sysoev et al., 2009; Sverlova, 2006). The species naturally occurs in xerothermal meadows along the edges of river valleys, hills, rock outcrops, as well as on remnants of meadows in quarries and in man-made habitats such as heaps. The species was rarely found at altitudes of $700 \mathrm{~m}$ above sea level. It is found in dry, open limestone areas, especially in short-sod pastures and less often in rocky habitats (Kerney, 1996). The paleoecological range of Ch. tridens (Muller, 1774) shows that the species is thermophilic, resistant to soil acidity, and prefers open habitats in central and South-Eastern Europe (Willis et al., 2000).

Chondrula tridens feeds on dead plant material and lays eggs in litter. It can penetrate in soil cracks during dry periods (Boschi, 2011). The shells can be several centimetres below the soil level. The lifespan of $C h$. tridens does not exceed several years, similarly to other small land snails (Schlütz et al., 2016). The detailed multiscale phenotypic analysis of Ch. tridens performed in Ukraine has showed that specimens with a larger shell and well-developed mouth armature are typical for arid conditions, while more moist areas are inhabited by smaller specimens with less developed mouth armature (Kramarenko, 2006).

The Ch. tridens species is common in the plain regions of Europe and is characterized by significant intraspecific diversity, which explains the identification of a large number of intraspecific taxa. The range of Ch. tridens martynovi subspecies comprises the mountainous and steppe Crimea, the left bank of the Black Sea lowland, the Azov lowland, the Donetsk and Azov Uplands with adjacent territories, in the west reaching the southeastern outskirts of the Dnieper Upland. In the west and south-west of Ukraine, it is completely replaced by Ch. tridens tridens. Ch. tridens martynovi inhabits a broad range of biotopes from open chalk slopes with pronounced xerothermic microclimatic conditions to floodplain forests. Most often, the subspecies is found in the steppe areas. Slightly stronger aperture teeth development compared to $C h$. tridens tridens indicates a better adaptation of this subspecies to the life in xerothermic biotopes (Gural-Sverlova et al., 2010). In the southem part of the steppe zone, the border between the spread zones of the two subspecies can run approximately along the course of the Dnipro. At the same time, in the north of the steppe zone, Ch. tridens martynovi can be found on both banks of the Dnieper (Gural-Sverlova et al., 2018). In this work, we will test three hypotheses: 1) the variation in the shape of Ch. tridens martynovi shells is influenced by the type of vegetation; 2) the variation in the shape of the shells of this species is influenced by the moisture regime of the biotope; and 3) the variation in the shape of the shells depends on the level of anthropogenic load.

\section{Materials and methods}

The empty and fully formed shells of Ch. tridens, were collected in 2019 within the basin of the Molochna River of the north-western Priazovye area (Fig. 1). Sampling points were made in settlements and beyond. They differed in vegetation, moisture regime and anthropogenic impact levels (Table 1). Expertly, the vegetation was identified to two alternative categories: grassy vegetation and tree plantations. According to the moisture level, the locations were xerophytic and mesoxerophytic. Anthropogenic load levels were assessed as low, medium and high.

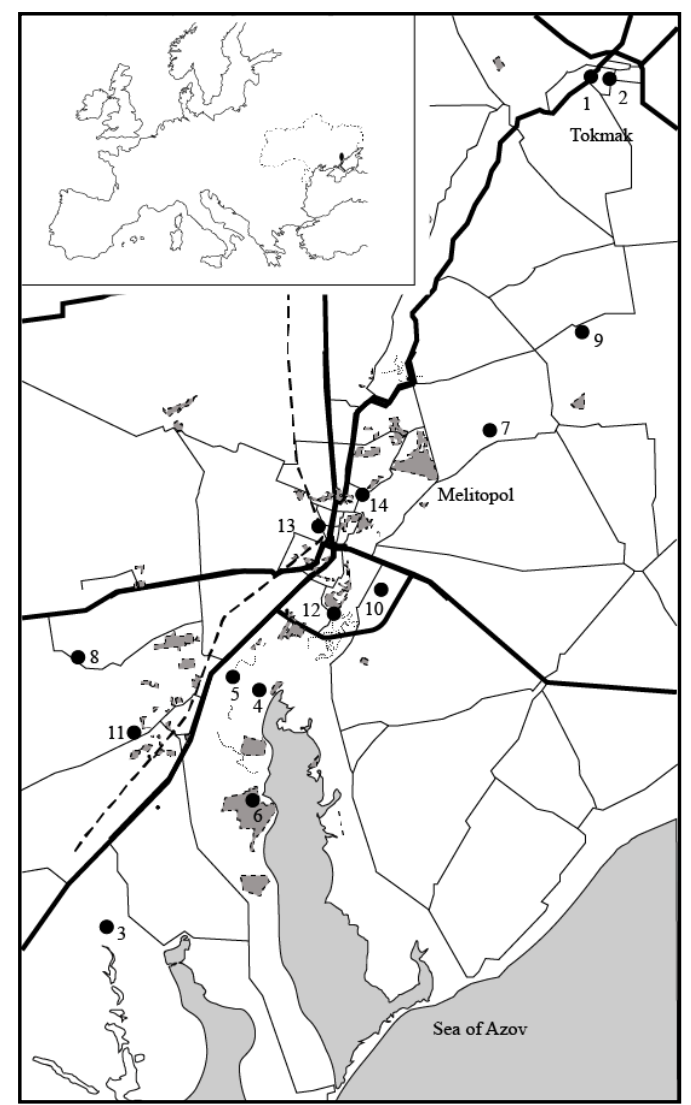

Fig. 1. Scheme of the collection locations of shells of Chondrula tridens: 1 - Tokmak town, deciduous tree plantation; 2 - Tokmak town, grassy vegetation; 3 - Davydivka village, deciduous tree plantation, 4 -Mirne village, deciduous tree plantation; 5 - Danilo-Ivanivka village, deciduous tree plantation; 6 - Bogatyr village, coniferous tree plantation; 7 - Tihonivka village, deciduous tree plantation; 8 - Polyanivka village, deciduous trees; 9 - Yasne village, grassy vegetation; 10 - Konstyantynivka village, grassy vegetation; 11 - Yakymivka town, grassy vegetation; 12 - Sadove village, grassy vegetation; 13 - Melitopil city, grassy vegetation; 14-Melitopil city, deciduous tree plantation

Table 1

Characteristics of collection points of Chondrula tridens in the north-western Azov Sea region

\begin{tabular}{|c|c|c|c|c|c|}
\hline Point number & Location & Type of vegetation & Humidity status & Level of anthropogenic load & Geographical coordinates \\
\hline 1 & Tokmak town & deciduous tree plantation & mesoxerophytic & medium & $47^{\circ} 15^{\prime} 11^{\prime \prime N} 35^{\circ} 41^{\prime} 40^{\prime \prime} \mathrm{E}$ \\
\hline 2 & Tokmak town & grassy vegetation & xerophytic & high & $47^{\circ} 14^{\prime} 03^{\prime \prime N} 35^{\circ} 41^{\prime} 37^{\prime \prime} \mathrm{E}$ \\
\hline 3 & Davydivka village & deciduous tree plantation & mesoxerophytic & low & $46^{\circ} 30^{\prime} 03^{\prime \prime} \mathrm{N} 35^{\circ} 11 ' 33^{\prime \prime} \mathrm{E}$ \\
\hline 4 & Mime village & deciduous tree plantation & xerophytic & medium & $46^{\circ} 43211^{\prime \prime N} 35^{\circ} 17 ' 51^{\prime \prime E}$ \\
\hline 5 & Danilo-Ivanivka village & deciduous tree plantation & xerophytic & medium & $46^{\circ} 453^{\prime \prime N} 35^{\circ} 1644^{\prime \prime} \mathrm{E}$ \\
\hline 6 & Bogatyr village & coniferous tree plantation & mesoxerophytic & low & $46^{\circ} 37^{\prime 2} 24^{\prime \prime N} 35^{\circ} 17 ' 52^{\prime \prime} \mathrm{E}$ \\
\hline 7 & Tihonivka village & deciduous tree plantation & mesoxerophytic & low & $46^{\circ} 56^{\prime} 24^{\prime \prime N} 35^{\circ} 33^{\prime} 09^{\prime \prime} \mathrm{E}$ \\
\hline 8 & Polyanivka village & deciduous tree plantation & mesoxerophytic & medium & $46^{\circ} 44^{\prime} 45^{\prime \prime N} 35^{\circ} 03^{\prime} 59^{\prime \prime} \mathrm{E}$ \\
\hline 9 & Yasne village & grassy vegetation & xerophytic & medium & $47^{\circ} 01^{\prime} 15^{\prime \prime} \mathrm{N} 35^{\circ} 39^{\prime} 08^{\prime \prime} \mathrm{E}$ \\
\hline 10 & Konstyantynivka village & grassy vegetation & xerophytic & medium & $46^{\circ} 49^{\prime} 37^{\prime \prime N} 35^{\circ} 2601^{\prime \prime} \mathrm{E}$ \\
\hline 11 & Yakymivka town & grassy vegetation & xerophytic & high & $46^{\circ} 40^{\prime} 01^{\prime \prime N} 35^{\circ} 08^{\prime} 27^{\prime \prime} \mathrm{E}$ \\
\hline 12 & Sadove village & grassy vegetation & mesoxerophytic & medium & $46^{\circ} 46^{\prime} 45^{\prime \prime N} 35^{\circ} 21^{\prime} 57^{\prime \prime} \mathrm{E}$ \\
\hline 13 & Melitopil city & grassy vegetation & xerophytic & high & $46^{\circ} 51^{\prime} 12^{\prime N} 35^{\circ} 21^{\prime} 57^{\prime \prime} \mathrm{E}$ \\
\hline 14 & Melitopil city & deciduous tree plantation & mesoxerophytic & low & $46^{\circ} 52^{\prime} 19^{\prime \prime} \mathrm{N} 35^{\circ} 25^{\prime} 08^{\prime \prime} \mathrm{E}$ \\
\hline
\end{tabular}


A total of 282 shells from 14 sampling plots were examined. Only intact shells of mature individuals, i.e. with a fully formed lip in the mouth, were used for analysis. The following parameters were measured for each shell: $\mathrm{WH}$ - shell spire height, $\mathrm{SH}$ - shell height, $\mathrm{MH}$ - shell aperture height, SW - shell width, MW - shell aperture width, the distance between the apices of the teeth: $a$ - columellar and parietal; $b$ - columellar and palatal; c-parietal and palatal (Fig. 2).

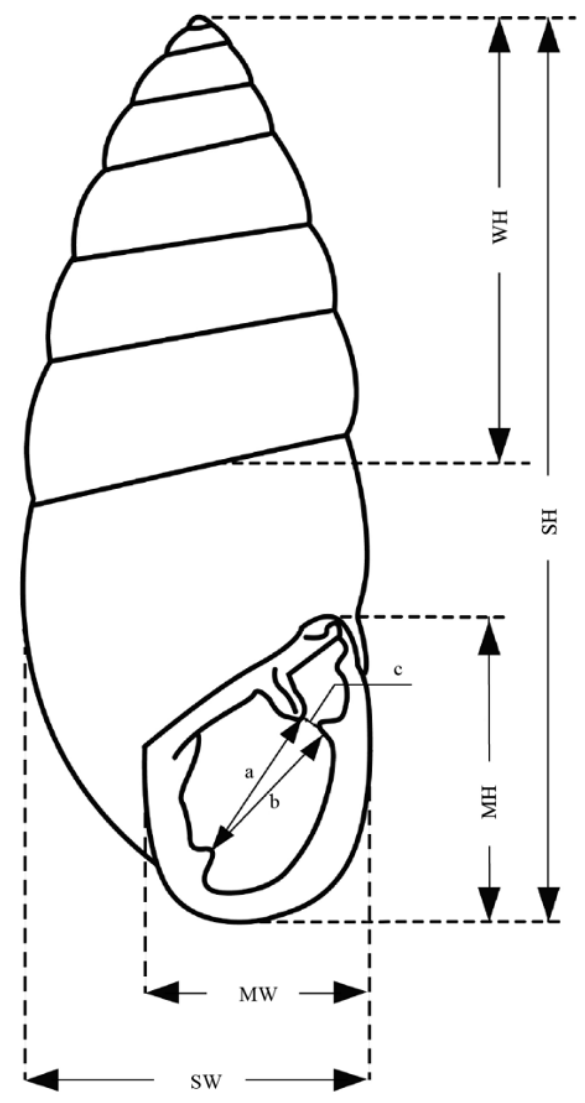

Fig. 2. Morphometric traits: WH - shell spire height, $\mathrm{SH}$ - shell height, $\mathrm{MH}$ - shell aperture height, SW - shell width, MW - shell aperture width, the distance between the apices of the teeth: a-columellar and parietal;

$\mathrm{b}$ - columellar and palatal; $\mathrm{c}$ - parietal and palatal

Chondrula tridens is characterized by the presence of mouth armature. In its fullest composition, it is represented by five teeth: angular, palatal, suprapalatal, columellar, parietal. Parietal and palatal teeth show weak interpopulation variability in the degree of their development. The other three teeth may undergo more or less significant reduction (until complete disappearance) (Shyleiko, 1984). The degree of the teeth development has been assessed both qualitatively and quantitatively. The degree of tooth development was assessed as follows: 0 - the tooth is completely absent, 1 - the tooth is poorly developed, 2 - the tooth is developed normally. To quantify the development of the oral armature in the mouth of each shell, the following indicators have been measured: the distance between the apices of the columellar and parietal teeth (a), the distance between the apices of the columellar and palatal teeth (b); the distance between the apices of the parietal and palatal teeth (c). All measurements have been performed under a MBS-9 binocular microscope with an accuracy of $0.1 \mathrm{~mm}$, or $0.05 \mathrm{~mm}$ (distance between teeth).

For each parameter, statistical indicators have been calculated: arithmetic mean (M) and standard deviation (SD) and coefficient of variation (CV). The morphological traits were processed by routine approaches using Statistica software (version 10.0, StatSoft, USA) (Brygadyrenko \& Korolev, 2015; Brygadyrenko \& Reshetniak, 2016; Komlyk \& Brygadyrenko, 2020). The size correction of morphometric traits was performed using the principal component analysis. The first principal component was considered as a marker of total shell size. Using the Multiple General Linear Model (MGLM) with principal component 1 as the predictor, the residuals were extracted, which in turn were also subjected to principal component analysis. Based on the principal components, cluster analysis was performed and clusters were identified. The clusters were interpreted using discriminant analysis and correspondence analysis.

\section{Results}

The morphological characteristics of Ch. tridens (Fig. 3, Table 2) demonstrate a significant component of variability, which is determined by the shell size. Correlation coefficients of morphological characters and principal component vary in the range of $0.58-0.77$ (Table 3 ). In general, the principal component 1 is able to describe $44.8 \%$ of the variability of morphological characteristics. The size of mollusks depends on locations $(\mathrm{F}=3.26, \mathrm{P}<0.001)$. Individuals from Tokmak town (grassy vegetation) and Sadove village (grassy vegetation) were the largest. If we take these locations out of consideration, then the role of location will not be a reliable factor that determines the mollusk size $(\mathrm{F}=2.99, \mathrm{P}=0.08$ according to the planned comparison test). The sizes of shells, which were quantitatively estimated using the principal component 1 , were statistically significantly independent of the vegetation type $(\mathrm{F}=2.10, \mathrm{P}=0.15)$ and the moisture regime of the habitat $(\mathrm{F}=1.10, \mathrm{P}=0.29)$. The shells size depended on the anthropogenic impact level $(\mathrm{F}=2.91, \mathrm{P}=0.05)$. Under conditions of high anthropogenic impact, the shells size increases. Mollusks from locations with low and medium anthropogenic impact do not differ in shell size $(\mathrm{F}=$ $0.37, \mathrm{P}=0.54$ according to planned comparison test).

The residuals were extracted from morphological characters as a result of applying the Multiple Linear Model. These remains are morphological characters without a dimensional component of variation. Three principal components were extracted after applying principal component analysis to them. The first three principal components, the eigenvalues of which exceed one, are capable of describing $76.6 \%$ of the variation in the attribute space. The principal component 1 indicates the opposite dynamics of morphological characters that describe the external dimensions of the shell to measurements that describe the mouth apparatus. Thus, the principal component 1 can be interpreted as the development degree of the mollusk mouth apparatus. The principal component 1 did not depend on the vegetation type $(\mathrm{F}=2.83, \mathrm{P}=0.10)$, but depended on the biotope moisture level $(\mathrm{F}=9.29, \mathrm{P}=0.002)$ and the anthropogenic transformation level $(\mathrm{F}=24.45, \mathrm{P}<0.001)$. Under xerophytic conditions, the principal component values were higher than under mesoxerophytic ones, indicating a relatively greater distance between the teeth of the aperture in moisture deficit conditions. The principal component 2 describes the opposite dynamics of the height measures in relation to width. Thus, the principal component 2 characterizes the elongation of the mollusk shell. It should be noted that the elongation of the shell shape is accompanied by an increase in the distance between the tops of the columellar and parietal teeth. The principal component 2 depended on the anthropogenic load level $(\mathrm{F}=$ $11.9, \mathrm{P}<0.001$ ). In the conditions of a greater anthropogenic load, mollusks with a less elongated (more spherical) shape were found. The principal component 3 indicates a restructuring in the organization of the mouth apparatus. An increase in the distances $\mathrm{a}$ and $\mathrm{b}$ was accompanied by a decrease in the distance $c$, which was associated with an increase in the shell aperture height and shell width. The principal component 3 depends on biotope moisture $(\mathrm{F}=17.47, \mathrm{P}<0.001)$ and the anthropogenic load level $(\mathrm{F}=8.27, \mathrm{P}<0.001)$. Under xerophytic conditions, individuals with a more elongated shell aperture were found.

Factor scores obtained from the principal component analysis represent characteristics of morphological characteristics that are sensitive to shape but not sensitive to shell size. They were used for cluster analysis. The obtained results allowed us to distinguish four clusters according to their homogeneity and notable isolation. Discriminate analysis with morphometric features as predictors confirmed the homogeneity of the identified clusters (Fig. 4). The first three discriminant functions made it possible to clearly identify clusters. Discriminant function 1 contrasts clusters 2 and 4 . Cluster 2 is characterized by increased values of indicators $a$ and $b$, but a decrease in shell and aperture widths. Accordingly, the opposite relationship was characteristic of cluster 4 . Discriminant function 2 distinguished cluster 3 from all others. Cluster 3 was characterized by increased shell and aperture widths, and shell aperture height, which was observed simultaneously with decrease in the $\mathrm{c}$ index and the severity of the angular 
and suprapalatal teeth. Discriminant function 3 distinguished cluster 1 from all the others. Representatives of this cluster were characterized by lower measurement values of the shell height and shell aperture width
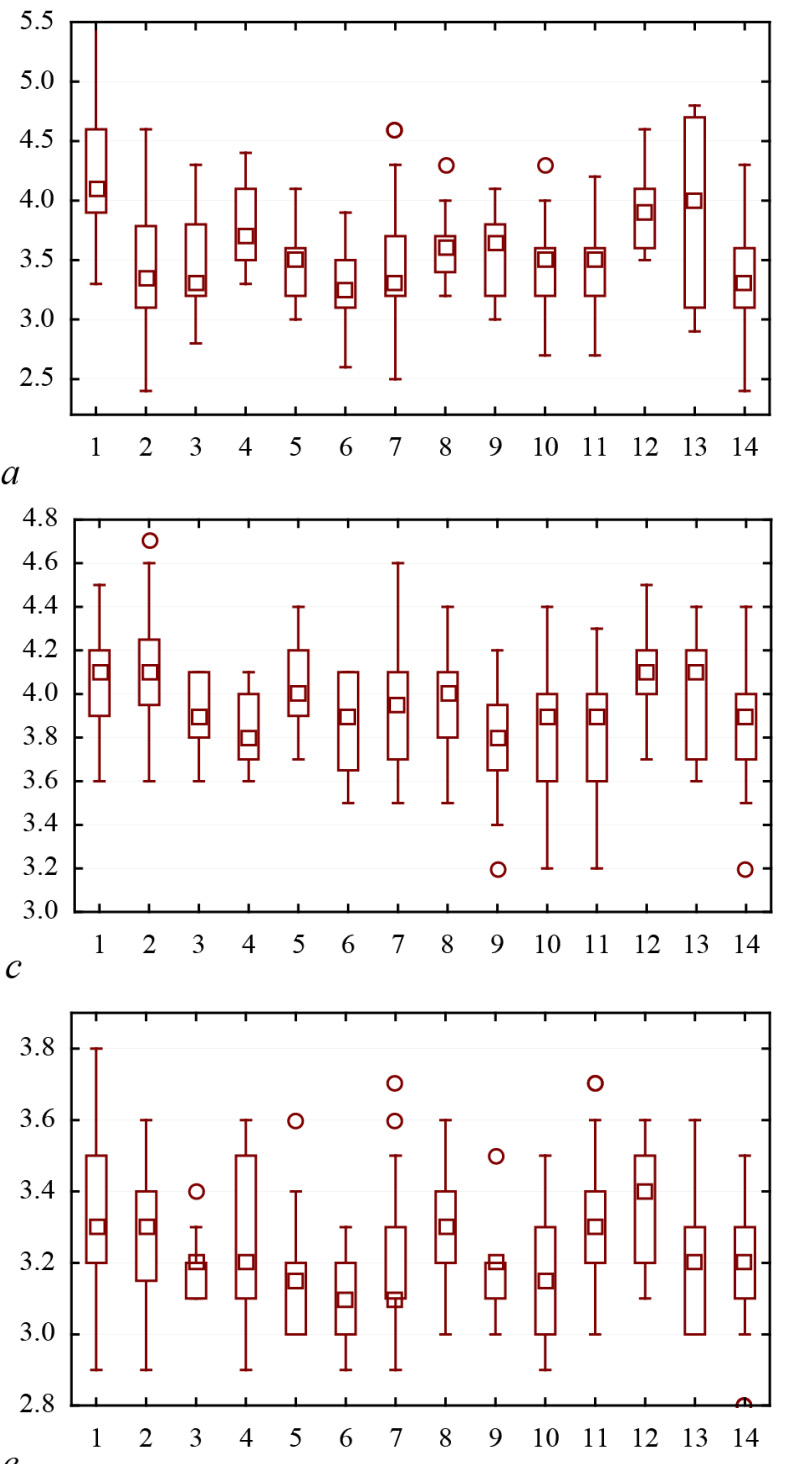

e

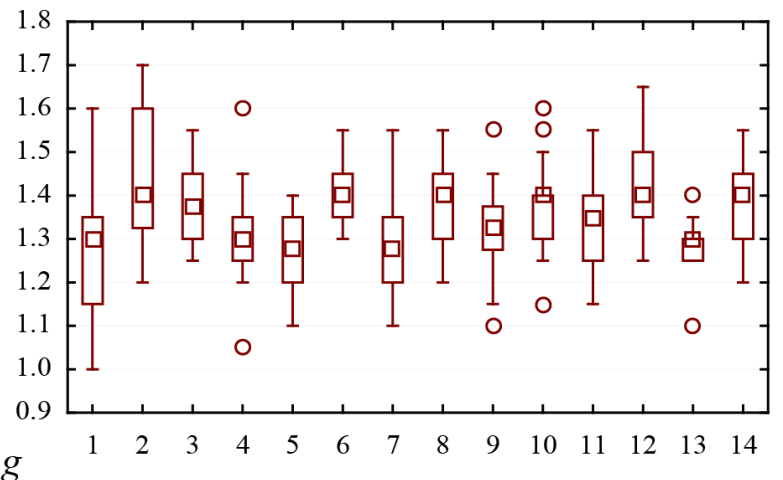

G

Fig. 3. Variability of morphological traits of the Chondrula tridens from different locations: the figure shows Box-Whisker plots with the whiskers indicating minimum and maximum, the box describing the range between first and third quartile, the square indicating the median and outliers shown by dots and crosses; on x-axis: 1 - Tokmak town, deciduous tree plantation; 2 - Tokmak town, grassy vegetation; 3 - Davydivka village, deciduous tree plantation, 4-Mirne village, deciduous tree plantation; 5 -Danilo-Ivanivka village, deciduous tree plantation; 6-Bogatyr village, coniferous tree plantation; 7 - Tihonivka village, deciduous tree plantation; 8-Polyanivka village, deciduous trees; 9 - Yasne village, grassy vegetation; 10 - Konstyantynivka village, grassy vegetation; 11 - Yakymivka town, grassy vegetation; 12 - Sadove village, grassy vegetation;

13 - Melitopil city, grassy vegetation; 14-Melitopil city, deciduous tree plantation; on y-axis are values of morphometric traits (mm): $\mathrm{a}$ - shell spire height $(\mathrm{WH}), \mathrm{b}$ - shell height $(\mathrm{SH}), \mathrm{c}$-shell aperture height $(\mathrm{MH}), \mathrm{d}$ - shell width (SW), e - shell aperture width (MW); the distance between the tops of the teeth: $\mathrm{f}$ - columellar and parietal (a); $g$ - columellar and palatal (b); $\mathrm{h}$ - parietal and palatal (c) 
Table 2

Degree of the angular, suprapalatal, and columellar tooth development (\%) in the aperture of the shell from different locations

\begin{tabular}{ccccccrccc}
\hline \multirow{2}{*}{ Location* } & \multirow{2}{*}{$\mathrm{N}$} & \multicolumn{3}{c}{ Angular(A) } & \multicolumn{3}{c}{ Suprapalatal(S) } & \multicolumn{3}{c}{ Columellar(C) } \\
\cline { 3 - 8 } & & $1^{* *}$ & 2 & 1 & \multicolumn{1}{c}{2} & \multicolumn{1}{c}{0} & 1 & 2 \\
\hline 1 & 34 & 25.8 & 74.2 & 65.0 & 35.0 & 5.8 & 61.7 & 32.5 \\
2 & 24 & 41.5 & 58.5 & 75.4 & 24.6 & 23.1 & 52.3 & 24.6 \\
3 & 10 & 27.3 & 72.7 & 100.0 & - & 4.5 & 95.5 & - \\
4 & 11 & 31.3 & 68.8 & 56.3 & 43.8 & 18.8 & 53.1 & 28.1 \\
5 & 10 & 37.0 & 63.0 & 33.3 & 66.7 & 11.1 & 55.6 & 33.3 \\
6 & 12 & 54.2 & 45.8 & 75.0 & 25.0 & 16.7 & 66.7 & 16.7 \\
7 & 26 & 42.5 & 57.5 & 38.4 & 61.6 & 4.1 & 63.0 & 32.9 \\
8 & 21 & 44.1 & 55.9 & 83.1 & 16.9 & 20.3 & 55.9 & 23.7 \\
9 & 12 & 19.4 & 80.6 & 77.4 & 22.6 & 6.5 & 58.1 & 35.5 \\
10 & 26 & 35.3 & 64.7 & 54.9 & 45.1 & 5.9 & 70.6 & 23.5 \\
11 & 37 & 47.1 & 52.9 & 66.1 & 33.9 & 10.7 & 54.5 & 34.7 \\
12 & 17 & 44.2 & 55.8 & 76.7 & 23.3 & 14.0 & 62.8 & 23.3 \\
13 & 13 & 19.4 & 80.6 & 38.7 & 61.3 & 6.5 & 58.1 & 35.5 \\
14 & 29 & 41.4 & 58.6 & 75.9 & 24.1 & 13.8 & 58.6 & 27.6 \\
Total & 282 & 37.5 & 62.5 & 65.0 & 35.0 & 11.2 & 60.1 & 28.7 \\
\hline
\end{tabular}

Notes: * 1 - Tokmak town, deciduous tree plantation; 2 - Tokmak town, grassy vegetation; 3 - Davydivka village, deciduous tree plantation, 4 -Mime village, deciduous tree plantation; 5 - Danilo-Ivanivka village, deciduous tree plantation; 6 - Bogatyr village, coniferous tree plantation; 7 - Tihonivka village, deciduous tree plantation; 8 - Polyanivka village, deciduous trees; 9 - Yasne village, grassy vegetation; 10 - Konstyantynivka village, grassy vegetation; 11 - Yakymivka town, grassy vegetation; 12 - Sadove village, grassy vegetation; 13 - Melitopil city, grassy vegetation; 14 - Melitopil city, deciduous tree plantation; $* *$ - degree of the angular, suprapalatal, and columellar tooth development in the aperture $(0$ - absent, 1 - moderate development; 2 - tooth is well developed).

Various combinations of the development of the teeth of the shell mouth are important for the cluster differentiation, as confirmed by discriminant analysis. In order to show the role of dental reinforcement for differentiation more clearly, we carried out multiple correspondence analysis (Fig. 5). The analysis revealed that the cluster 1 shells were characterized by moderate development of the angular tooth. Cluster 3 was characterized by a well-developed angular and suprapalatal teeth. For cluster 4, a well-developed columellar tooth was typical. According to the degree of development of the mouth teeth, representatives of cluster 2 had an intermediate position between representatives of the other clusters. Thus, the identified clusters had quantitative morphological features that allowed us to identify their morphotypes. Each sampling point was characterized by different morphotypes combination, according to which the sampling points can be classified (Fig. 6). The main trend was increase in representatives of morphotype 4 due to decrease in representatives of morphotypes 2 and 3. In this trend, representatives of morphotype 1 first increased their presence and then decreased. Multiple correspondence analyses made it possible to assess the role of environmental factors in determining the morphotypic diversity of mollusk populations. Morphotype 1 corresponds to biotopes with a low anthropogenic load level, morphotype 4 corresponds to biotopes with a high anthropogenic load. Morphotypes 2 and 3 correspond to a moderate level of anthropogenic load. Vegetation type was not an important factor in determining the morphotypic diversity of populations. Morphotypes 2 and 3 were more common in xerophytic conditions, while morphotypes 1 and 4 were more common in mesoxerophytic conditions.

\section{Discussion}

The species occupies an geographical area where the conditions of life vary greatly (Preston, 1948; Lawton, 1999; McGill et al., 2007). The broader the range of the species, the more varied the conditions to which the species needs to adapt (Verberk et al., 2010; Sokolov et al., 2014; Zimaroeva et al., 2016). Phenotypic plasticity is the genotype ability to produce various phenotypes under different conditions (Holloway, 2002; Fusco \& Minelli, 2010; Kunakh et al., 2019). Phenotypic plasticity allows snails to manage environmental challenges (Madec et al., 2000; Munn et al., 2017). The phenotypic plasticity is a key mechanism that allows species to have and adaptively maintain a broad range of geographic distribution (Pichancourt et al., 2012; O'Hanlon et al., 2017).
The phenotypic plasticity is expected to allow species to more effectively shift their geographic range in response to changing climate (Merilä et al., 2014; Leicht et al., 2017; Nicolai \& Ansart, 2017). There are many species of pulmonate snails in arid, semi-arid, and Mediterranean regions where the climate has a high temperature environment and low humidity (Mizrahi et al., 2010). Land snails are unable to change their distribution rapidly in response to climatic changes. Therefore, rising temperatures and associated drought rapidly bring them to the critical limits of their existence (Dillon et al., 2010). Thermal deaths of snails occur as a result of high temperatures, even in regions with a temperate climate (Schmidt-Nielsen et al., 1971; McQuad et al., 1979; Kunakh et al., 2018). This initiates subsequent desiccation, which may lead to intermittent mass mortalities (Nicolai et al., 2010). In land snail populations commonly found in arid or semi-arid regions, heat-related mortality tends to be quite low (Nicolai \& Ansart, 2017).

\section{Table 3}

Results of the principal component analysis of the morphometric traits, multiple general linear model (MGLM) of the morphological traits with shell size (principal component 1 scores) as predictor and the principal component analysis of the MGLM-residuals

\begin{tabular}{|c|c|c|c|c|c|c|c|}
\hline \multirow[t]{2}{*}{ Variable* } & \multirow{2}{*}{$\begin{array}{l}\text { Principal com- } \\
\text { ponent analysis } \\
\text { of the morpho- } \\
\text { metric traits }\end{array}$} & \multicolumn{3}{|c|}{$\begin{array}{l}\text { Multiple general } \\
\text { linear model } \\
\text { (MGLM) }\end{array}$} & \multicolumn{3}{|c|}{$\begin{array}{l}\text { Principal component } \\
\text { analysis of the } \\
\text { MGLM-residuals }\end{array}$} \\
\hline & & $R_{a d j}^{2}$ & $F$ & $P$ & $\mathrm{PC1}$ & $\mathrm{PC} 2$ & PC3 \\
\hline WH & 0.58 & 0.34 & 145.5 & $<0.001$ & -0.77 & 0.45 & -0.25 \\
\hline $\mathrm{SH}$ & 0.75 & 0.56 & 362.2 & $<0.001$ & -0.87 & 0.40 & - \\
\hline $\mathrm{MH}$ & 0.77 & 0.60 & 415.2 & $<0.001$ & -0.63 & - & 0.56 \\
\hline SW & 0 & 0.49 & 266.2 & 0.001 & -0.12 & -0.80 & 0.14 \\
\hline MW & 0.69 & 0.48 & 261.3 & $<0.001$ & -0.53 & -0.63 & - \\
\hline $\mathrm{a}$ & 0.77 & 0.59 & 408.5 & $<0.001$ & 0.70 & 0.35 & 0.39 \\
\hline$b$ & 0.76 & 0.58 & 386.3 & $<0.001$ & 0.76 & - & 0.28 \\
\hline $\mathrm{c}$ & 0.64 & 0.41 & 196.1 & $<0.001$ & 0.53 & - & -0.76 \\
\hline Variation explained, \% & 44.8 & - & - & - & 42.37 & 19.12 & 15.11 \\
\hline
\end{tabular}

Notes: * - WH - shell spire height, $\mathrm{SH}$ - shell height, $\mathrm{MH}$ - shell aperture height, SW - shell width, MW - shell aperture width, the distance between the tops of the teeth: $\mathrm{a}-$ columellar and parietal; $\mathrm{b}$ - columellar and palatal; $\mathrm{c}$ - parietal and palatal.

The temperature of a snail's body depends on the morphological traits of the shell (Cowie, 1990; Anderson et al., 2007; Miller et al., 2011). The size of the shell plays an important role due to the mathematical fact that for a given shape, the smaller the object, the greater its surface-tovolume ratio. This means that smaller snails heat up faster than larger ones. A faster decrease in temperature was demonstrated in smaller individuals when airflow was constant (Knigge et al., 2017). The optimal surface to volume ratio depended on the aridity of the habitat. Snails had larger shells in Mediterranean locations at low latitudes that were drier compared to shells in more northern and humid locations (Giokas et al., 2014). The variability in the size of the shell aperture is a morphological feature to which the thermal and water balance of the mollusk is related. They tend to be smaller in dry environments, which probably reduces water loss (Goodfriend, 1986). Two strategies evolved in different snail species with respect to shell texture to minimize water loss. Ribbed shells retain more water on the external surface, while smooth shells have lower water permeability (Giokas et al., 2014).

Intraspecific differentiation is an important aspect of adaptation to living conditions within the range (Kunakh et al., 2018). The ecological factors are not the only cause of intraspecific diversity. The cause of intraspecific diversity may be historical, genetic or geographic in nature, as well as of random nature. The body size of animals of the same species depends on the degree of habitat suitability in terms of the availability of resources and stability of environmental conditions. The reproductive health, climate resilience, predator pressure, energy requirements, and quality and quantity of food sources correlate with invertebrate body size (Wardhaugh et al., 2013). There is a relationship between habitat quality and body size of land snails. Animals reach their largest sizes in optimal conditions (Mammola et al., 2019; Tytar, 2021). The data obtained indicate that the total shell sizes of mollusks from different biotopes were quite homogeneous. This allows us to suggest that the animals are in the conditions of the optimal. Such a result is quite natural, since the studies were performed in the territory located in the center of the subspecies range, for 
which exactly the optimal conditions are characteristic by definition. The human impact is an important gradient that deviates the conditions from the optimum. Under the conditions of anthropogenic impact, the size of shells increases. Our results are in agreement that human disturbance at the landscape level benefited snails by creating suitable habitats and reducing avian predation pressure. Refuge and moisture conditions are related to the distribution and abundance of snails at the microscale level (Rosin et al., 2017).

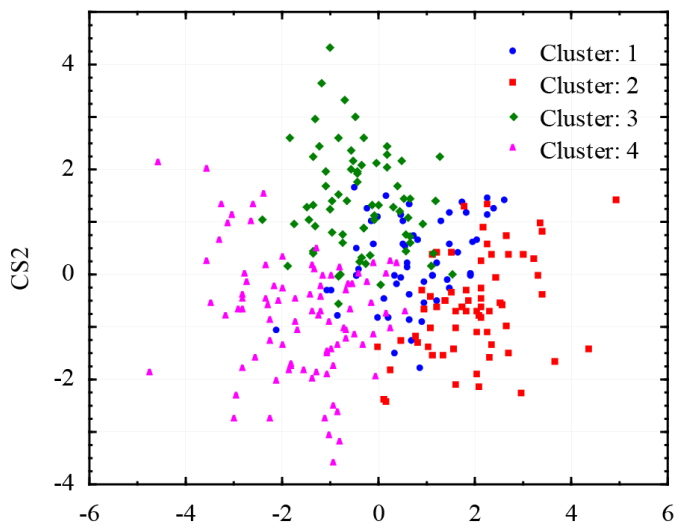

$a$

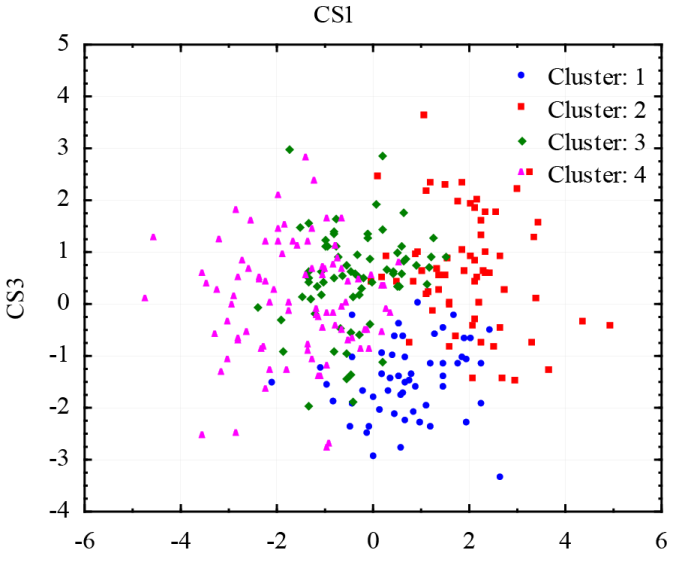

$b$

CS1

Fig. 4. Location of shells in the space of the first three discriminant functions: the abscissa and ordinate axes are canonical scores; $a$ - location of shells in the space of the CS1 and CS2 discriminant functions; $b-$ location of shells in the space of the CS1 and CS3 discriminant functions

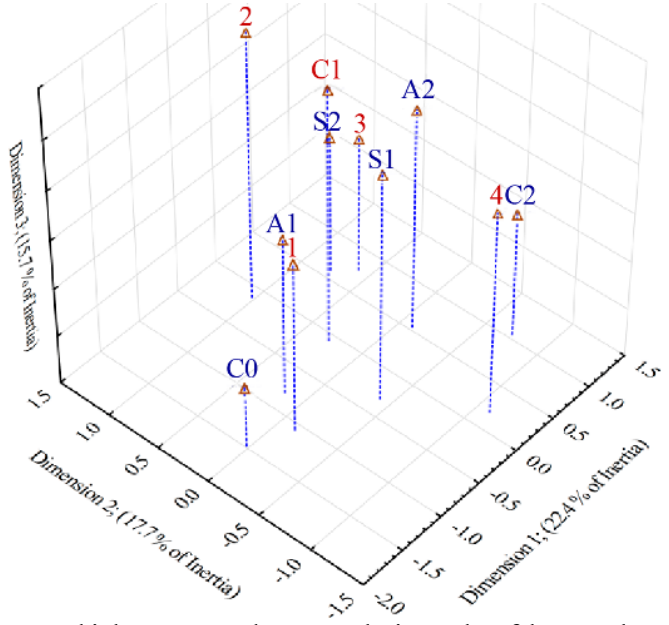

Fig. 5. Multiple correspondences analysis results of the morphotypes (clusters) and aperture teeth: 1, 2,3,4-cluster numbering, A- angular tooth $(1$ - moderate development, 2 - tooth is well developed), $\mathrm{S}$ - suprapalatal teeth (1 - moderate development, 2 - tooth is well developed), $\mathrm{C}$ - columellar ( 0 -absent, 1 - moderate development, 2 - tooth is well developed)
Table 4

General discriminant analysis of mollusk morphotypes based on morphological traits

\begin{tabular}{|c|c|c|c|c|c|c|c|}
\hline Effect & $\begin{array}{c}\text { Level of } \\
\text { effect }\end{array}$ & $\begin{array}{l}\text { Wilk's } \\
\text { lambda }\end{array}$ & $F$ & $P$ & $\begin{array}{c}\text { Function } \\
1 \\
\end{array}$ & $\begin{array}{c}\text { Function } \\
2 \\
\end{array}$ & $\begin{array}{c}\text { Function } \\
2 \\
\end{array}$ \\
\hline$\overline{\mathrm{WH}}$ & - & 0.77 & 3.17 & 0.02 & 0.04 & -0.23 & 0.51 \\
\hline $\mathrm{SH}$ & - & 0.96 & 1.55 & 0.20 & 0.03 & -0.07 & 0.47 \\
\hline $\mathrm{MH}$ & - & 0.98 & 5.06 & $<0.001$ & 0.05 & 0.22 & 0.32 \\
\hline SW & - & 0.94 & 35.82 & $<0.001$ & -0.30 & 0.31 & -0.07 \\
\hline MW & - & 0.71 & 19.19 & $<0.001$ & -0.32 & 0.17 & 0.22 \\
\hline $\mathrm{a}$ & - & 0.82 & 6.00 & $<0.001$ & 0.26 & 0.06 & -0.27 \\
\hline b & - & 0.94 & 13.59 & $<0.001$ & 0.20 & 0.12 & -0.34 \\
\hline $\mathrm{c}$ & - & 0.86 & 32.07 & $<0.001$ & -0.10 & -0.45 & -0.40 \\
\hline A & 1 & 0.73 & 0.62 & 0.60 & 0.05 & -0.18 & -0.21 \\
\hline $\mathrm{S}$ & 1 & 0.99 & 3.58 & 0.01 & -0.08 & -0.20 & -0.28 \\
\hline $\mathrm{C}$ & 0 & 0.96 & 0.76 & 0.61 & 0.17 & 0.08 & -0.17 \\
\hline $\mathrm{C}$ & 1 & 0.98 & 0.26 & 0.85 & 0.17 & 0.03 & -0.02 \\
\hline $\mathrm{A} \times \mathrm{S}$ & 1 & 1.00 & 0.66 & 0.69 & 0.03 & 0.09 & -0.20 \\
\hline $\mathrm{A} \times \mathrm{C}$ & 1 & 0.99 & 1.56 & 0.16 & -0.04 & 0.02 & -0.11 \\
\hline $\mathrm{A} \times \mathrm{C}$ & 2 & 0.96 & 0.75 & 0.61 & -0.03 & -0.06 & -0.12 \\
\hline $\mathrm{S} \times \mathrm{C}$ & 1 & 0.98 & 3.17 & 0.02 & 0.01 & 0.11 & -0.26 \\
\hline $\mathrm{S} \times \mathrm{C}$ & 2 & 0.77 & 1.55 & 0.20 & -0.08 & -0.03 & -0.26 \\
\hline $\mathrm{A} \times \mathrm{S} \times \mathrm{C}$ & 1 & 0.96 & 5.06 & $<0.001$ & -0.05 & -0.15 & -0.03 \\
\hline $\mathrm{A} \times \mathrm{S} \times \mathrm{C}$ & $?$ & 0.98 & 35.82 & $<0.001$ & -0.03 & -0.09 & -0.03 \\
\hline \multicolumn{8}{|c|}{$\chi^{2}$ tests with successive roots removed } \\
\hline Eigenvalue & - & - & - & - & 1.88 & 0.77 & 0.60 \\
\hline Canonical R & - & - & - & - & 0.81 & 0.66 & 0.61 \\
\hline $\begin{array}{l}\text { Wilk's } \\
\text { lambda }\end{array}$ & - & - & - & - & 0.12 & 0.35 & 0.63 \\
\hline$\chi^{2}$ & - & - & - & - & 565.59 & 280.88 & 126.45 \\
\hline df & - & - & - & - & 57.00 & 36.00 & 17.00 \\
\hline$p$-value & - & - & - & - & $<0.001$ & $<0.001$ & $<0.001$ \\
\hline
\end{tabular}

Notes: * - WH - shell spire height, $\mathrm{SH}$ - shell height, $\mathrm{MH}$ - shell aperture height, SW - shell width, MW - shell aperture width; the distance between the tops of the teeth: a - columellar and parietal; b - columellar and palatal; c-parietal and palatal; degree of the tooth development in the aperture of the Chondrula tridens: $\mathrm{A}$ - angular, $\mathrm{S}$ - suprapalatal, $\mathrm{C}$ - columellar.

Table 5

Descriptive statistics of morphometric traits of the Chondrula tridens morphotypes $(\mathrm{x} \pm \mathrm{SD})$

\begin{tabular}{|c|c|c|c|c|c|c|c|c|c|}
\hline \multirow{2}{*}{$\begin{array}{l}\text { Morpho- } \\
\text { types }\end{array}$} & \multirow{2}{*}{$\mathrm{N}$} & \multicolumn{8}{|c|}{ Morphometric traits* } \\
\hline & & $\mathrm{WH}$ & SH & MH & SW & MW & $a$ & $b$ & $c$ \\
\hline \multirow[b]{2}{*}{1} & & $3.23 \pm$ & $9.22 \pm$ & $3.83 \pm$ & $4.35 \pm$ & $3.15 \pm$ & $1.38 \pm$ & $1.44 \pm$ & $0.44 \pm$ \\
\hline & 57 & 0.37 & 0.70 & 0.29 & 0.20 & 0.18 & 0.13 & 0.12 & 0.11 \\
\hline \multirow{2}{*}{2} & & $3.87 \pm$ & 10.00 & $3.97 \pm$ & $4.19 \pm$ & $3.13 \pm$ & $1.35 \pm$ & $1.37 \pm$ & $0.38 \pm$ \\
\hline & 65 & 0.49 & \pm 0.67 & 0.23 & 0.15 & 0.14 & 0.11 & 0.10 & 0.10 \\
\hline \multirow{2}{*}{3} & 70 & $3.57 \pm$ & $9.80 \pm$ & $4.05 \pm$ & $4.46 \pm$ & $3.32 \pm$ & $1.29 \pm$ & $1.35 \pm$ & $0.32 \pm$ \\
\hline & 70 & 0.53 & 0.68 & 0.20 & 0.20 & 0.18 & 0.11 & 0.11 & 0.08 \\
\hline \multirow{2}{*}{4} & 90 & $3.68 \pm$ & $9.73 \pm$ & $3.87 \pm$ & $4.41 \pm$ & $3.30 \pm$ & $1.25 \pm$ & $1.31 \pm$ & $0.44 \pm$ \\
\hline & 90 & 0.52 & 0.78 & 0.28 & 0.24 & 0.20 & 0.12 & 0.13 & 0.11 \\
\hline \multirow{2}{*}{ Total } & 282 & $3.60 \pm$ & $9.71 \pm$ & $3.93 \pm$ & $4.36 \pm$ & $3.23 \pm$ & $1.31 \pm$ & $1.36 \pm$ & $0.40 \pm$ \\
\hline & & 0.53 & 0.76 & 0.27 & 0.23 & 0.19 & 0.13 & 0.13 & 0.11 \\
\hline
\end{tabular}

Notes: * - WH - shell spire height, $\mathrm{SH}$ - shell height, $\mathrm{MH}$ - shell aperture height, SW - shell width, MW - shell aperture width, the distance between the tops of the teeth: $\mathrm{a}$ - columellar and parietal; $\mathrm{b}$ - columellar and palatal; $\mathrm{c}-$ parietal and palatal.

Table 6

Degree of the angular, suprapalatal, and columellar tooth development (\%) in the aperture of the Chondrula tridens morphotypes

\begin{tabular}{crrrrrrrr}
\hline \multirow{2}{*}{ Morphotype (Cluster) } & \multirow{2}{*}{$\mathrm{N}$} & \multicolumn{3}{c}{ Angular(A)* Suprapalatal(S) } & \multicolumn{3}{c}{ Columellar(C) } \\
\cline { 3 - 9 } & & 1 & 2 & 1 & 2 & 0 & 1 & 2 \\
\hline 1 & 57 & 54.4 & 45.6 & 78.9 & 21.1 & 24.6 & 63.2 & 12.3 \\
2 & 65 & 43.1 & 56.9 & 55.4 & 44.6 & 12.3 & 75.4 & 12.3 \\
3 & 70 & 21.4 & 78.6 & 47.1 & 52.9 & 12.9 & 61.4 & 25.7 \\
4 & 90 & 42.2 & 57.8 & 76.7 & 23.3 & 7.8 & 53.3 & 38.9 \\
Total & 282 & 39.7 & 60.3 & 64.9 & 35.1 & 13.5 & 62.4 & 24.1 \\
\hline
\end{tabular}

Notes: * - degree of the angular, suprapalatal, and columellar tooth development in the aperture ( 0 -absent, 1 - moderate development; 2 - tooth is well developed).

The morphological properties after the exclusion of the size component, form three main trends of variability. They can be meaningfully interpreted. Thus, the main component 1 represents the level of development of aperture apparatus. Its development depends on the level of bio- 
tope humidity. The elongation of the form is characterized by the principal component 2 . The shape of mollusk shells strongly depends on the anthropogenic impact. The elongation of shell aperture is characterized by the principal component 3 . The changes in this component depend on both humidity and the level of anthropogenic load. Thus, changes in both shape and size of mollusk shells are closely related to the level of anthropogenic load and, to a lesser extent, to the moisture content in the biotope. In a number of cases, anthropogenic influence forms monotonous gradations of variability of morphological characters. This situation is observed when increasing anthropogenic impact leads to a more pronounced development of one or another morphological pattern. There are also situations when the maximum manifestation of a pattern was observed at an average level of load. Such a non-linear dependence can be considered as a result of disturbance of morphogenetic processes under anthropogenic impact, which acts as a destabilizing factor

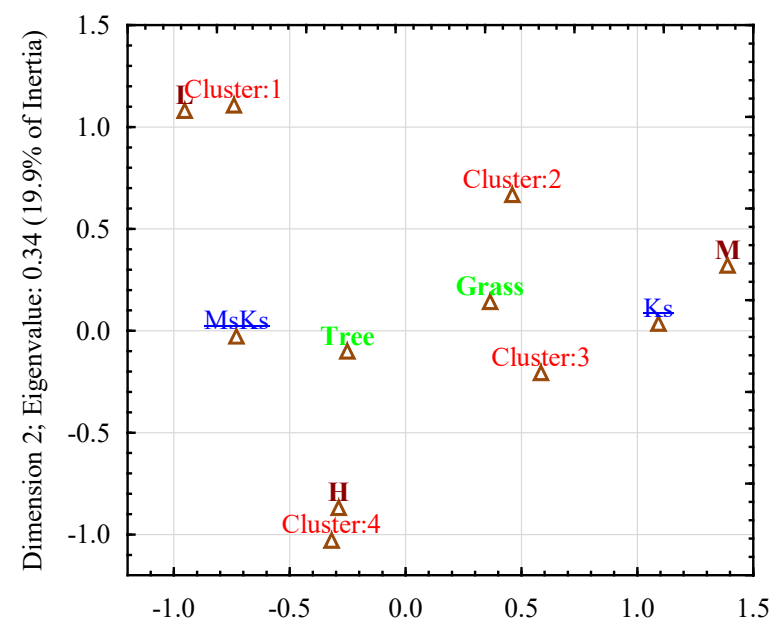

Dimension 1; Eigenvalue: 0.49 (28.4\% of Inertia)

Fig. 6. Multiple correspondence analysis of morphotypes (Cluster 1,2,3,4), vegetation types (Grass - grass vegetation, Tree - tree vegetation), moisture regime (Ks - xerophytic, MsKs - mesoxerophytic) and level of anthropogenic load ( $\mathrm{L}$ - low, $\mathrm{M}$ - medium, $\mathrm{H}$ - high); $\mathrm{x}$-axis and $\mathrm{y}$-axis are dimensions extracted as a result of multiple correspondence analysis

On the basis of morphological characteristics, mollusks may be divided into four clusters. The clusters are well separable by statistical methods, but the boundaries between clusters are continuous. Therefore, the selected clusters may only have the status of morphotypes. If the morphotypes are ecologically conditioned, they may be identified as ecomorphotypes. Also, the genetic conditioning of these morphotypes cannot be excluded. This presumption was confirmed by the fact that morphotypes correlate quite well with the degree of expression of individual teeth in the aperture. The level of development of the aperture is certainly of adaptive importance, but the development of individual teeth should be considered as a genetically determined trait. Individual populations are represented by aggregates of morphotypes. The morphotype structure may be explained by ecological factors. Vegetation is an important factor that determines the organization of terrestrial invertebrate communities at different scale levels (Yorkina et al., 2018; Zhukov et al., 2019). It is of interest to assess the influence of vegetation cover on morphological features of land mollusks. The role of vegetation is not significant in the framework of the present study. Obviously, to solve this question, it is necessary to assess the influence of vegetation at different scale levels (Zymaroieva et al., 2019; Zhukov et al., 2019). The anthropogenic impact has an important role in the formation of the morphotype structure (Kunakh et al., 2018). Mollusks have considerable potential for indicating anthropogenic pressures (Yorkina et al., 2019). The morphotype 1 is confined to biotopes with low levels of anthropogenic pressure. These animals are smaller in size than those that inhabit higher levels of anthropogenic pressure. They are also characterized by a relatively large distance between the teeth of the aperture. The level of angular, suprapalatal, and columellar development is somewhat lower than such of the other morphotypes. Thus, ecological peculiarities are combined with quite distinct set of morphological characters. The morphotype 4 is most often found in conditions with increased anthropogenic pressure. These are animals whose sizes are relatively larger than such of those living under less anthropogenic pressure. The morphotypes 2 and 3 are more common under moderate anthropogenic pressure and in xerophytic conditions.

\section{Conclusion}

The role of environmental factors in the morphological variability of mollusk shells $C h$. tridens is still unclear, despite a significant number of studies on this problem. The results presented in this study expand the knowledge of the morphological variability of $C h$. tridens and support the hypothesis that some anthropogenic factors are the most important drivers that determine the variability of shell morphology. The obtained results suggest that populations of $C h$. tridens martynovi are represented by a variety of morphological types that allow snails to adapt to regimes of natural environmental factors and anthropogenic load. The variation of dimensional characteristics of populations specifies their homogeneity that is a consequence of optimality of living conditions of this species in steppe biotopes and anthropogenic ecosystems derived from them. The morphotypes distinguished based on the features of the shell shape differ in preferences of different conditions. The main gradients that cause a regular response in the morphotypic structure are the anthropogenic load and moisture regime.

The studied materials were stored in the malacological collection of the State $\mathrm{Mu}$ seum of Natural History in Lviv. The authors are grateful to the Candidate of Biological Sciences, senior researcher of the State Museum of Natural History of the National Academy of Sciences of Ukraine, head of laboratory of malacology of the State Museum of Natural History of the National Academy of Sciences of Ukraine N. V. Gural-Sverlova for valuable comments and recommendations.

\section{References}

Anderson, C., Epperson, B., Fortin, M., Holderegger, R., James, P., Rosenberg, M., Scribner, K., \& Spear, S. (2010). Considering spatial and temporal scale in landscape-genetic studies of gene flow. Molecular Ecology, 19(17), 3565-3575.

Anderson, T. K., Weaver, K. F., \& Guralnick, R. P. (2007). Variation in adult shell morphology and life-history traits in the land snail Oreohelix cooperi in relation to biotic and abiotic factors. Journal of Molluscan Studies, 73(2), 129-137.

Barker, G. M. (2005). The character of the New Zealand land snail fauna and communities: Some evolutionary and ecological perspectives. Records of the Western Australian Museum, 68(1), 53-102.

Boschi, C. (2011). Die Schneckenfauna der Schweiz: Ein umfassendes Bild- und Bestimmungsbuch. Haupt, Bern.

Brygadyrenko, V. V., \& Korolev, O. V. (2015). Morphological polymorphism in an urban population of Pterostichus melanarius (Illiger, 1798) (Coleoptera, Carabidae). Graellsia, 71(1), e025.

Brygadyrenko, V., \& Reshetniak, D. (2016). Morphometric variability of Clitellocephalus ophoni (Eugregarinida, Gregarinidae) in the intestines of Harpalus rufipes (Coleoptera, Carabidae). Archives of Biological Sciences, 68(3), 587-601.

Cowie, R. H. (1990). Climatic selection on body colour in the land snail Theba pisana (Pulmonata: Helicidae). Heredity, 65(1), 123-126.

Dillon, M. E., Wang, G., \& Huey, R. B. (2010). Global metabolic impacts of recent climate warming. Nature, 467(7316), 704-706.

Fusco, G., \& Minelli, A. (2010). Phenotypic plasticity in development and evolution: Facts and concepts. Philosophical Transactions of the Royal Society B: Biological Sciences, 365(1540), 547-556.

Giokas, S., Pall-Gergely, B., \& Mettouris, O. (2014). Nonrandom variation of morphological traits across environmental gradients in a land snail. Evolutionary Ecology, 28(2), 323-340.

Goodfriend, G. A. (1986). Variation in land-snail shell form and size and its causes: A review. Systematic Biology, 35(2), 204-223.

Gural-Sverlova, N. V., \& Gural, R. I. (2010). Novye taksony nazemnyh mollyuskov iz rodov Chondrula i Brephulopsis (Enidae) s territorii Ukrainy [New taxa of the land molluscs of the genera Chondrula and Brephulopsis (Enidae) from the territory of Ukraine]. Ruthenica, 20(1), 1-12 (in Russian).

Gural-Sverlova, N. V., Busel, V. A., \& Gural, R. I. (2018). Vidovoj sostav nazemnyh mollyuskov Zaporozhskoj oblasti i vliyanie na nego antropohorii [Species composition of land molluscs of Zaporozhye region and anthrogenic influence on it]. Ruthenica, 28(3), 101-112 (in Russian). 
Holloway, G. J. (2002). Phenotypic plasticity: Beyond nature and nurture. Heredity, $89(6), 410-410$.

Horsak, M., Chytry, M., Danihelka, J., Koci, M., Kubesova, S., Lososova, Z., Otypkova, Z., \& Tichy, L. (2010). Snail faunas in the Southem Ural forests and their relations to vegetation: An analogue of the Early Holocene assemblages of Central Europe? Journal of Molluscan Studies, 76(1), 1-10.

Kerney, M., Cameron, R., \& Riley, G. (1996). A field guide to the land snails of Britain and North-West Europe. Collins, London.

Kerney, M. P., Cameron, R. A., \& Jungbluth, J. H. (1983). Die Landschnecken Nord und Mitteleuropas. Parey, Hamburg.

Knigge, T., Di Lellis, M. A., Monsinjon, T., \& Köhler, H. R. (2017). Relevance of body size and shell colouration for thermal absorption and heat loss in white garden snails, Theba pisana (Helicidae), from Northern France. Joumal of Thermal Biology, 69, 54-63.

Komlyk, V., \& Brygadyrenko, V. (2020). Morphological variability of Bembidion varium (Coleoptera, Carabidae) in gradient of soil salinity. Folia Oecologica, 47(1), 23-33.

Kramarenko, S. S., \& Sverlova, N. V. (2003). Do vyvchennia vnutrishnovydovoi minlyvosti Chondrula tridens (Gastropoda, Pulmonata, Buliminidae) na zakhodi Ukrainy ta ziasuvannia taksonomichnoho statusu okremykh form [The study of intraspecific variation of Chondrula tridens (Gastropoda, Pulmonata, Buliminidae) in western Ukraine and determination of the taxonomic status of certain forms]. Proceedings of the State Natural History Museum, (18), 93-110 (in Ukrainian).

Kramarenko, S. S., \& Sverlova, N. V. (2006). Mizhpopuliatsiina minlyvist konkholohichnykh oznak nazemnoho moliuska Chondrula tridens (Buliminidae) Pivnichno-Zakhidnoho Prychomomoria [Interpopulation variability of conchological traits of the terrestrial mollusk Chondrula tridens (Buliminidae) in the Northwestern Black Sea Region]. Proceedings of the State Natural History Museum, 22, 105-118 (in Ukrainian).

Kunakh, O. N., Kramarenko, S. S., Zhukov, A. V., Kramarenko, A. S., \& Yorkina, N. V. (2018). Fitting competing models and evaluation of model parameters of the abundance distribution of the land snail Vallonia pulchella (Pulmonata, Valloniidae). Regulatory Mechanisms in Biosystems, 9(2), 198-202.

Kunakh, O. N., Kramarenko, S. S., Zhukov, A. V., Zadorozhnaya, G. A., \& Kramarenko, A. S. (2018). Intra-population spatial structure of the land snail Vallonia pulchella (Müller, 1774) (Gastropoda; Pulmonata; Valloniidae). Ruthenica, 28(3), 91-99.

Kunakh, O., \& Kovalenko, D. (2019). Fitting competing models of the population abundance distribution: Land snails from Nikopol Manganese Ore Basin technosols. Ekologia Bratislava, 38(4), 367-381.

Lawton, J. H. (1999). Are there general laws in ecology? Oikos, 84(2), 177-192.

Leicht, K., Seppala, K., \& Seppala, O. (2017). Potential for adaptation to climate change: Family-level variation in fitness-related traits and their responses to heat waves in a snail population. BMC Evolutionary Biology, 17(1), 140.

Madec, L., Bellido, A., \& Guiller, A. (2003). Shell shape of the land snail Cornu aspersum in North Africa: Unexpected evidence of a phylogeographical splitting. Heredity, 91(3), 224-231.

Madec, L., Desbuquois, C., \& Coutellec-Vreto, M. (2000). Phenotypic plasticity in reproductive traits: Importance in the life history of Helix aspersa (Mollusca: Helicidae) in a recently colonized habitat. Biological Joumal of the Linnean Society, 69(1), 25-39.

Mammola, S., Milano, F., Vignal, M., Andrieu, J., \& Isaia, M. (2019). Associations between habitat quality, body size and reproductive fitness in the alpine endemic spider Vesubia jugorum. Global Ecology and Biogeography, 28(9), 1325-1335.

Manel, S., Joost, S., Epperson, B., Holderegger, R., Stopfer, A., Rosenberg, M., Scribner, K, Bonin, A., \& Fortin, M. (2010). Perspectives on the use of landscape genetics to detect genetic adaptive variation in the field. Molecular Ecology, 19(17), 3760-3772.

Martin, K., \& Sommer, M. (2004). Relationships between land snail assemblage patterns and soil properties in temperate-humid forest ecosystems. Joumal of Biogeography, 31(4), 531-545.

McGill, B., Etienne, R., Gray, J., Alonso, D., Anderson, M., Benecha, H., Dornelas, M., Enquist, B., Green, J., He, F., Hurlbert, A., Magurran, A., Marquet, P., Maurer, B., Ostling, A., Soykan, C., Ugland, K., \& White, E. (2007). Species abundance distributions: Moving beyond single prediction theories to integration within an ecological framework. Ecology Letters, 10(10), 995-1015.

McQuad, C. D., Branch, G. M., \& Frost, P. G. (1979). Aestivation behaviour and thermal relations of the pulmonate Theba pisana in a semi-arid environment. Journal of Thermal Biology, 4(1), 47-55.

Merila, J., \& Hendry, A. (2014). Climate change, adaptation, and phenotypic plasticity: The problem and the evidence. Evolutionary Applications, 7(1), 1-14.

Miller, L. P., \& Denny, M. W. (2011). Importance of behavior and morphological traits for controlling body temperature in littorinid snails. The Biological Bulletin, 220(3), 209-223.

Mizrahi, T., Heller, J., Goldenberg, S., \& Arad, Z. (2010). Heat shock proteins and resistance to desiccation in congeneric land snails. Cell Stress and Chaperones, 15(4), 351-363.
Munn, A., \& Treloar, M. (2017). Phenotypic plasticity in the common garden snail: Big guts and heavier mucus glands compete in snails faced with the dual challenge of poor diet and coarse substrate. Joumal of Comparative Physiology B, 187(4), 545-561.

Nicolai, A., \& Ansart, A. (2017). Conservation at a slow pace: Terrestrial gastropods facing fast-changing climate. Conservation Physiology, 5(1), 1-17.

Nicolai, A., Filser, J., Lenz, R., Bertrand, C., \& Charrier, M. (2010). Adjustment of metabolite composition in the haemolymph to seasonal variations in the land snail Helix pomatia. Joumal of Comparative Physiology B, 181, 457-466.

O’Hanlon, A., Feeney, K., Dockery, P., \& Gormally, M. (2017). Quantifying phenotype-environment matching in the protected Kerry spotted slug (Mollusca: Gastropoda) using digital photography: Exposure to UV radiation determines cryptic colour morphs. Frontiers in Zoology, 14(1), 35.

Pichancourt, J. B., \& van Klinken, R. D. (2012). Phenotypic plasticity influences the size, shape and dynamics of the geographic distribution of an invasive plant. PLoS One, 7(2), e32323.

Preston, F. W. (1948). The commonness and rarity of species. Ecology, 29(3), 254 283.

Riedel, A. (1988). Slimaki ladowe Gastropoda terrestria. Katalog Fauny Polski. 36. PWN, Warszawa.

Rosin, Z., Lesicki, A., Kwieciński, Z., Skórka, P., \& Tryjanowski, P. (2017). Land snails benefit from human alterations in rural landscapes and habitats. Ecosphere, 8(7), e01874.

Schileyko, A. A. (1984). Fauna SSSR. Mollyuski. Nazemnyye mollyuski podotryada Pupillina fauny SSSR (Gastropoda, Pulmonata, Geophila). Tom 3, vypusk 3. [Fauna of the USSR. Mollusks, vol. 3, part 3: (Terrestrial Mollusks of the Suborder Pupillina (Gastropoda, Pulmonata, Geophila) of the Fauna of the USSR)]. Nauka, Leningrad (in Russian).

Schileyko, A. A. (2016). Functional interrelations between conchological and anatomical characters in Stylommatophora (Mollusca, Gastropoda). Archives of Zoological Museum of Lomonosov Moscow State University (54), 269-297.

Schlutz, F., \& Bittmann, F. (2016). Dating archaeological cultures by their moats. A case study from the early bronze age settlement fidvar near vrable, SW Slovakia. Radiocarbon, 58(2), 331-343.

Schmidt-Nielsen, K., Taylor, C., \& Shkolnik, A. (1971). Desert snails: Problems of heat, water and food. The Journal of Experimental Biology, 55(2), 385-398.

Snegin, E. A. (2011a). The genetic structure of populations of model species of terrestrial mollusks under conditions of urbanized landscape: A case study of Chondrula tridens (Gastropoda, Pulmonata). Ekological Genetics, 9(2), 54-64.

Snegin, E. A. (2011b). The role of the principle of the founder in the formation of gene pools of adventitious colonies: A case study of Chondrula tridens (Gastropoda, Pulmonata). Zoologichesky Zhurnal, 90(6), 643-648.

Sokolov, S. G., \& Zhukov, A. V. (2014). Variation trends in the parasite assemblages of the Chinese sleeper Perccottus glenii (Actinopterygii: Odontobutidae) in its native habitat. Biology Bulletin, 41(5), 468- 477.

Sverlova, N. V. (2006). O rasprostranenii nekotoryh vidov nazemnyh mollyuskov na territorii Ukrainy [On the distribution of some species of land molluscs on the territory of Ukraine]. Ruthenica, 16, 119-139.

Sysoev, A., \& Schileyko, A. (2009). Land snails and slugs of Russia and adjacent countries. Pensoft, Sofia, Moscow.

Thomassen, H., Buermann, W., Mila, B., Graham, C., Cameron, S., Schneider, C., Pollinger, J., Saatchi, S., Wayne, R., \& Smith, T. (2010). Modeling environmentally associated morphological and genetic variation in a rainforest bird, and its application to conservation prioritization. Evolutionary Applications, 3(1), 1-16.

Tytar, V. (2021). Associations between habitat quality and body size in the Carpathian-Podolian land snail Vestia turgida (Gastropoda, Clausiliidae): Species distribution model selection and assessment of performance. Zoodiversity, 55(1), 25-40.

Verberk, W., Velde, G., \& Esselink, H. (2010). Explaining abundance-occupancy relationships in specialists and generalists: A case study on aquatic macroinvertebrates in standing waters. Journal of Animal Ecology, 79(3), 589-601.

Wardhaugh, C. W., Edwards, W., \& Stork, N. E. (2013). Body size variation among invertebrates inhabiting different canopy microhabitat: Flower visitors are smaller. Ecological Entomology, 38(1), 101-111.

Welter-Schultes, F. (2012). European non-marine molluscs. A guide for species identification. Planet Poster Editions, Gottingen.

Welter-Schultes, F. W. (2000). The pattem of geographical and altitudinal variation in the land snail Albinaria idaea from Crete (Gastropoda: Clausiliidae). Biological Journal of the Linnean Society, 71(2), 237-250.

Willis, K., Rudner, E., \& Sumegi, P. (2000). The full-glacial forests of Central and Southeastem Europe. Quaternary Research, 53(2), 203-213.

Yorkina, N., Maslikova, K., Kunah, O., \& Zhukov, O. (2018). Analysis of the spatial organization of Vallonia pulchella (Muller, 1774) ecological niche in technosols (Nikopol Manganese Ore Basin, Ukraine). Ecologica Montenegrina, 17, 29-45.

Yorkina, N., Zhukov, O., \& Chromysheva, O. (2019). Potential possibilities of soil mesofauna usage for biodiagnostics of soil contamination by heavy metals. Ekologia Bratislava, 38(1), 1-10. 
Zhukov, O., Kunah, O., Dubinina, Y., Fedushko, M., Kotsun, V., Zhukova, Y., \& Potapenko, O. (2019). Tree canopy affects soil macrofauna spatial patterns on broad- and meso-scale levels in an Eastern European poplar-willow forest in the floodplain of the River Dnipro. Folia Oecologica, 46(2), 101-114.

Zhukov, O., Kunah, O., Dubinina, Y., Zhukova, Y., \& Ganzha, D. (2019). The effect of soil on spatial variation of the herbaceous layer modulated by overstorey in an Eastern European poplar-willow forest. Ekologia Bratislava, 38(3), 253-272.
Zimaroeva, A. A., Zhukov, O. V., \& Ponomarenko, O. L. (2016). Determining spatial parameters of the ecological niche of Parus major (Passeriformes, Paridae) on the base of remote sensing data. Vestnik Zoologii, 50(3), 251-258.

Zymaroieva, A., Zhukov, O., Fedonyuk, T., \& Pinkin, A. (2019). Application of geographically weighted principal components analysis based on soybean yield spatial variation for agro-ecological zoning of the territory. Agronomy Research, 17(6), 2460-2473. 